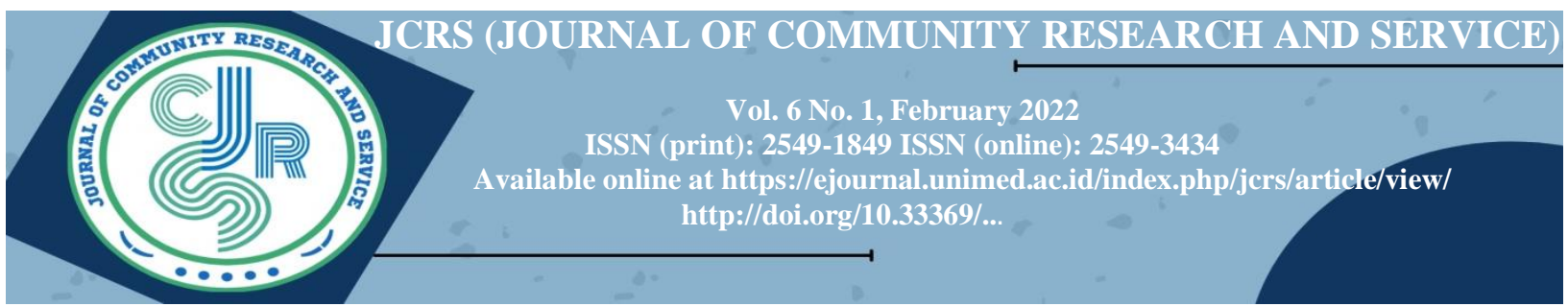

\title{
Preservation by Socializing the Benefits and Nutritional Content of Simalungun Tinuktuk Spices to Women's Organization of Simalungun Central Bureau of Statistics
}

\author{
${ }^{1}$ Marini Damanik, ${ }^{2}$ Ida Duma Riris, ${ }^{3}$ Lisnawaty Simatupang, ${ }^{4}$ Angel \\ Fransisca Manurung, ${ }^{5}$ Tia Aulia Surbakti, ${ }^{6}$ Syarifah Ayuni, ${ }^{7}$ Alex Munte, \\ ${ }^{8}$ Kristian Simatupang
}

1,2,3,4,5,6,7,8 Universitas Negeri Medan, INDONESIA

Imarini@unimed.ac.id

\begin{abstract}
Preservation of Simalungun's Typical Spices to the community of the women's organization of Simalungun Central Bureau of Statistics by the Medan State University Research and Service Center, namely tinuktuk spices, have been carried out by socializing the benefits and contents of which have been carried out online. Preserving these tinuktuk spices as a form of community service by the Medan State University Research and Service Center by socializing the benefits and nutritional content of tinuktuk spices to find out how the nutrition of the Simalungun spices is. In the online socialization meeting, not only the introduction of the Simalungun tinuktuk spices but also the nutritional content and benefits of the tinuktuk spices were also socialized. This is also related to the importance of nutritional needs to increase body immunity during the COVID-19 period. In the process of socializing efforts to preserve the benefits and nutritional content of Simalungun's special spices, there was a significant difference in results between the pre-test and post-test, namely in the pre-test $43 \%$ and post-test $84 \%$, and this indicates that participants know the benefits and nutritional content of Simalungun's typical tinuktuk spices. This community service activity went smoothly because the participant already knew about the nutritional content and benefits of Simalungun's typical tinuktuk spices and the tinuktuk spices can be preserved.
\end{abstract}

Keywords: Tinuktuk spices, benefits, nutritional content, COVID 19

Article history: Received: 05-12-2021; Revised: 16-12-2022; Accepted: 15-02-2022; Available online: 26-02-2022 How to cite this article: Damanik, M., Riris, I.D., and Simatupang, L., et.al. (2022) Preservation by Socializing the Benefits and Nutritional Content of Simalungun Tinuktuk Spices to Women's Organization of Simalungun Central Bureau of Statistics. Journal of Community Research and Service,6(1),

https://doi.org/10.14710/ijred.x.X.Xxx-Xxx

\section{Introduction}

Indonesia is one of the countries that produce spices and herbs in the world. Some herbal plants belong to the spice group. The use of spices and herbs has been widely used, both in the food and health industries.

One of the uses of spices and herbs as spices, from Simalungun Regency, North Sumatra province. Tinuktuk is very well known in the Simalungun community. Since the days of the Simalungun Batak ancestors, Tinuktuk has been a spice and herbal condiment that is nutritious for the user and is quite popular. Tinuktuk itself comes from the word "ti" which means "which", while the word "nuktuk" means "mashed", so the meaning of the word Tinuktuk is mashed. But now it is difficult to find in traditional Batak markets, even typical Batak restaurants. It is difficult to get this Tinuktuk spices, due to the traditional way of making it. In addition to the variety of spices and herbs, the dose of spices and herbs must also be right. Tinuktuk spices ingredients are made from a variety of spices and herbs such as black, red ginger, kencur, shallots, garlic, candlenut, and salt [1].

Like other types of Batak food that has a spicy taste. The spicy and hot taste of tinuktuk is the same as chili sauce in general which is suitable for increasing appetite. The benefits of tinuktuk are: it makes the 
body fit, especially for those who often work hard, warms the body, makes sleep soundly, can increase appetite, and for postpartum mothers it can help clean dirty blood [2].

Initially this Tinuktuk was only used as a side dish to eat which is usually eaten using boiled vegetables. Furthermore, Tinuktuk spices is better eaten mixed with carp, mujahir, grilled tilapia. In the typical Simalungun Batak cuisine it is known as Tinombur. Tinuktuk spices doused with hot water, then smeared on grilled fish or meat [3].

The main ingredients of Tinuktuk chili sauce are red ginger and black pepper. The efficacy of red ginger has been proven based on research that has been done that it can cure all kinds of diseases. Such as laxatives, stomach stimulants, wheezing, vomiting and muscle aches, nearsightedness, leprosy, ulcers, fever, body heat, taste improvement, digestion improvement, heart disease. And as a drug to combat the symptoms of the disease (alophatia). In addition, red ginger rhizome has antioxidant, antibacterial, antiinflammatory, anticancer, antimutagenic, and antitumor activities [4]. Black pepper itself is rich in piperine as an active ingredient, contains essential oils, oleoresins, and alkaloids [5]. Pepper also contains lots of vitamin A and $\mathrm{K}$, dietary fiber, calcium, magnesium, potassium, manganese, phosphorus, and carotene [6].

\section{Method}

Based on the problems raised in this independent community service activity, the approach method used is the method of education and socialization. 1) Observing the condition of partners to identify the problems they face related to the typically Simalungun spices, tinuktuk. 2) Conducting an education in the form of introduction to Tinuktuk, nutrition and benefits of Tinuktuk and also making Tinuktuk. 3) Conducting socialization about Tinuktuk as an immune enhancer in the face of the COVID-19 virus pandemic through a forum group discussion which was attended by 36 women of Dharma Wanita BPS Simalungun and 3 lecturers and 5 students from FMIPA UNIMED which is a team from LPPM Unimed.

\section{Results and Discussion}

The introduction of tinuktuk as a form of community service by the Medan State University Research and Service Institute by socializing the benefits and nutritional content of tinuktuk spices from Simalungun in dealing with the New Normal Covid-19 has been carried out to the women's organization of Simalungun Central Bureau of Statistics.

The first meeting which was a Forum Group Discussion (FGD) was held online on September 24, 2021 by the service team of the Medan State University Research and Service Institute and women's organization of Simalungun Central Bureau of Statistics. In this online meeting, there were 36 women dharma women from BPS Simalungun and 3 lecturers from FMIPA UNIMED and 5 students who were a team from State University of Medan Research and Service.

In this FGD event, Prof. Dr. Ida Duma Riris, M.Si where an explanation about the tinuktuk spices and the ingredients used and the content contained in each of these ingredient as well as an explanation of nutrition fulfillment and immune enhancement during the new normal Covid-19 period.

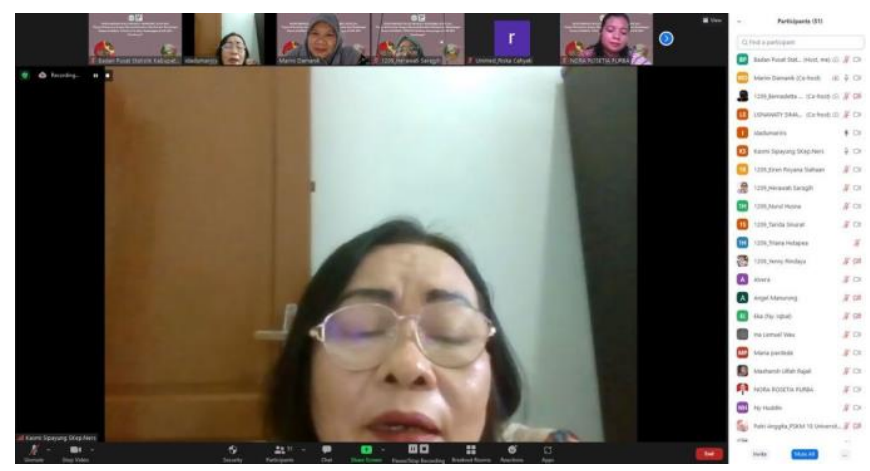

Fig. 1. Socializing of Tinuktuk by forum grup discussion. 
On the same day, a discussion or question and answer process were carried out as well as answering online quizzes regarding the socialization of tinuktuk spices that had been carried out at the beginning of the meeting, where the results of the pre-test quiz showed that $43 \%$ of the participants of this socialization knew about tinuktuk spices and its contents and benefits. Women's organization of Simalungun Central Bureau of Statistics has enthusiasm for this socialization.

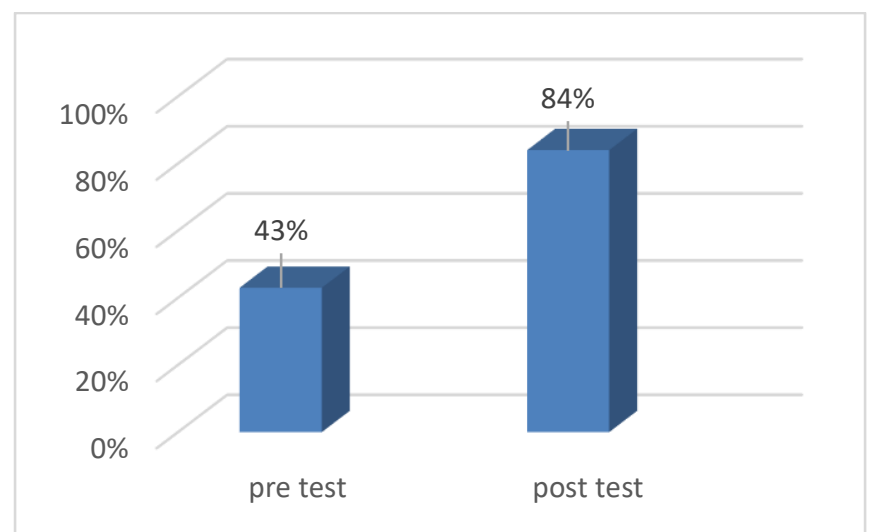

Fig. 2. Pre-test and Post-test during socialization of Tinuktuk.

The post-test quiz was conducted after the presentation of Tinuktuk. It was found that $84 \%$ of the participants already knew a lot about tinuktuk. Based on the results of the quiz, there was a significant difference of $41 \%$ that the participants knew about the tinuktuk, how it is made, the ingredients for making it, the benefits, and what content is in the tinuktuk. Thus, the tinuktuk knew and can also be preserved and it is hoped that it can add insight into Simalungun's special tinuktuk spices and be useful as an immune enhancer in the era of the Covid-19 pandemic.

\section{Conclusion}

Based on the pretest and post-test conducted on mothers regarding tinuktuk spices, both the introduction to tinuktuk spices, manufacture, ingredients, benefits, and nutritional content, there was a significant difference in the results, namely $41 \%$ where the pre-test results were $43 \%$ and the post-test results were $84 \%$. Participants in the socialization knew about the tinuktuk spices, the benefits and nutritional content of the tinuktuk spices. Based on the socialization regarding tinuktuk spices that was carried out, it is hoped that knowledge about tinuktuk spices will increase and can also be used as an immune enhancer in the era of the Covid-19 pandemic.

Acknowledgments. Women's organization of Simalungun Central Bureau of Statistics and the Medan State University Research and Service Institute.

\section{References}

[1] Saragih SN. Tinuktuk sebagai pengobatan tradisional pasca melahirkan di Nagori Amborokan Panel Raya. Kecamatan Raya Kahean. Kabupaten Simalungun. Undergraduate thesis. UNIMED; 2016.

[2] Sianipar, David CR, Erick S. Eksistensi Tinuktuk pada masyarakat Batak Simalungun. Program Studi Sastra Batak. Fakultas Ilmu Budaya. USU; 2019.

[3] Holong Online Magazine. 2018. http://www.majalahholongonline.com/2018/04/nikmati-tinuktuksambal-rempah.html. Diakses 3 Oktober 2021.

[4] Sitorus CR. Formulasi Dan Uji Aktivitas Antibakteri Nanogel Ekstrak Rimpang Jahe Merah (Zingiber officinale Rosc. Var. Rubrum) Terhadap Bakteri Propionibacterium acnes dan Staphylococcus epidermidis. Underegraduate thesis. USU; 2021.

[5] Shaikh J, Bhosale R, Singhal R. Microencapsulation of black pepper oleoresin. Food Chemistry. 2006; 94(1):105-110. 
[6] Zachariah TJ, Safeer AL, Jayarajan K, Leela NK, Vipin TM, Saji KV, Shiva KN, Parthasarathy VA, Mammootty KP. Correlation of metabolites in the leaf and berries of selected black pepper varieties. Scientia Horticulturae. 2010; 123(3):418-422. 